\title{
PENGEMBANGAN BAHAN AJAR PENGETAHUAN LINGKUNGAN BERBASIS WEB UNTUK MENINGKATKAN MOTIVASI MAHASISWA IKIP BUDI UTOMO MALANG
}

\author{
Farizha Irmawati ${ }^{1)}$, Ika Oktaviana ${ }^{2)}$, Lia Rahayu ${ }^{3)}$ \\ 1,2,3 IKIP Budi Utomo Malang \\ e-mail: Farizha99@gmail.com, Ikaoktaviana71@gmail.com
}

Diterima 2 Februari 2016, Disetujui 22 Maret 2016

\begin{abstract}
The development of rapid information technology makes learners freed in obtaining teaching materials. One of them is a web-based teaching materials. The purpose of the research is to produce a web-based teaching materials on the subjects of Environmental Sciences to enhance student motivation Budi Utomo Malang Teachers' Training College. Development of teaching materials based website using ADDIE models. Development research was conducted from April to December 2015. Based on the results of validation material obtained from the value of $80 \%$ and the media expert validation and design to get the value of $93.75 \%$ and $83.33 \%$, it means that the teaching materials developed have been fit for use as an ingredient supporting teaching Environmental Science course, but still be revised on the advice and comments from experts as well as students. Web-based teaching materials have been developed and tested on students can create and enhance motivation sebesar 85,75.\%.
\end{abstract}

Keywords: teaching materials, website, motivation

\section{PENDAHULUAN}

Lembaga yang berperan serta dalam perkembangan ilmu pendidikan adalah pendidikan tinggi. Pendidikan tinggi merupakan kelanjutan pendidikan menengah yang mencakup program diploma, program sarjana, program magister, program doktor dan program profesi, serta program spesialis. Perguruan tinggi menyiapkan peserta didik menjadi anggota masyarakat yang memiliki kemampuan akademis, atau professional yang dapat menerapakan, mengembangkan, atau menciptakan ilmu pengetahuan dan teknologi atau kesenian (Keputusan Menteri Pendidikan Nasional RI No 232/U/2000).

Wijayanto (2009) mengungkapkan bahwa pendidikan tinggi merupakan sekumpulan masyarakat akademis, yaitu masyarakat ilmu pengetahuan yang mempunyai otonomi ilmu pengetahuan berupa kebebasan akademis dalam setiap disiplin ilmu, sesuai dengan prinsip dan metode masing-masing. Pendidikan tinggi dituntut untuk menghasilkan produk bermutu yang sesuai dengan kebutuhan dan harapan (Nasution, 2012). Salah satu produk dari perguruan tinggi berupa bahan ajar, yang merupakan salah satu sumber belajar, yakni segala sesuatu yang memudahkan peserta didik memperoleh sejumlah informasi pengetahuan, pengalaman, dan keterampilan dalam proses belajar mengajar.

Lembaga yang berperan serta dalam perkembangan pendidikan tinggi salah satunya adalah IKIP Budi Utomo, terdapat Program Studi Pendidikan Biologi yang merupakan salah satu program akademik, yang disediakan di Fakultas Pendidikan Ilmu Eksata dan Keolahragaan (FPIEK). 
Ada beberapa mata kuliah yang diselenggarakan di Program Studi Pendidikan Biologi dan Program Studi Pendidikan Matematika, salah satunya matakuliah Pengetahuan Lingkungan.

Berdasarkan hasil angket yang disebar, diperoleh informasi bahwa belum ada bahan ajar Pengetahuan Lingkungan yang yang terbatas pada buku teks saja dan mahasiswa tidak semuanya memiliki sehingga mahasiswa cenderung mencari sumber materi dari internet. Hasil wawancara dosen pengampu matakuliah yang menyatakan bahwa sumber belajar Pengetahuan Lingkungan masih bersifat umum dan dalam bentuk textbook, powerpoint, diktat atau jurnal. Berdasarkan hasil observasi diketahui bahwa belum ada bahan ajar berbasis website yang menjelaskan tentang mata kuliah Pengetahuan Lingkungan yang sesuai dengan kurikulum pada IKIP Budi Utomo.

Pemilihan model pengembangan yang digunakan adalah ADDIE didasarkan atas pemikiran bahwa model ini: 1) memberikan kesempatan untuk melakukan revisis (evaluasi) secara terus menerus dalam setiap tahap yang dilalui sehingga dapat menghasilkan sesuatu, bahan ajar yang lebih baik, 2) model ADDIE sangat sederhana namun implementsinya sistematik (Muriati, 2013). Prosedur yang dilakukan sesuai dengan tujuan yang diharapkan pengembang yang meliputi menganalisis, mendesain, mengembangkan, mengimplementasi dan mengevaluasi. Pemilihan model ini didasari atas pertimbangan bahwa model ini dikembangkan secara sistematis dan berpijak pada landasan teoretis desain pembelajaran.

Berdasarkan uraian di atas, maka tujuan penelitian untuk mengembangkan bahan ajar berbasis website matakuliah Pengetahuan Lingkungan untuk meningkatkan motivasi belajar.

\section{METODE}

Prosedur penelitian pengembangan bahan ajar berupa buku teks penunjang matakuliah Pengetahuan Lingkungan dilakukan dengan mengacu pada model pengembangan Model ADDIE (Branch, 2009). Model ini disusun secara terprogram dengan urutan-urutan kegiatan yang sistematis dalam upaya pemecahan masalah belajar yang berkaitan dengan sumber belajar yang sesuai dengan kebutuhan dan karakteristik pebelajar.

Model ini terdiri atas lima langkah, yaitu: (1) analyze (analisis), (2) design (perancangan), (3) development (pengembangan), (4) implementasi (implementation), dan (5) evaluation (evaluasi), disajikan pada Gambar 1.

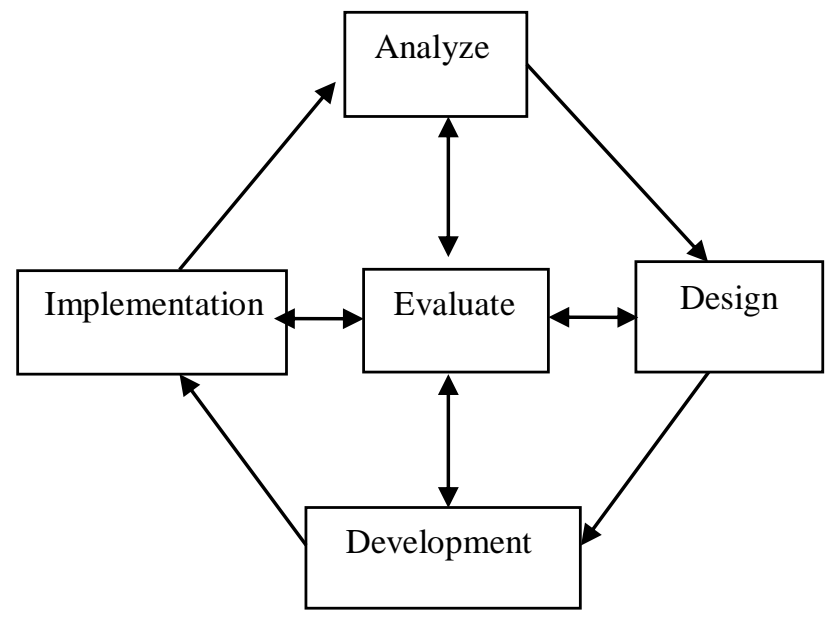

Gambar 1. Prosedur Pengembangan Model ADDIE (Branch, 2009)

\section{Analyze/Analisis}

Tahap analisis dilakuakan dengan mengidentifikasi dan mengembangkan pemahaman yang jelas tentang kebutuhan peserta didik mengenai bahan ajar Pengetahuan Lingkungan. Hal ini disebut dengan tahap analisis kebutuhan, terdapat dua tahapan dalam analisis ini yaitu: a) analisisi kurikulum dan b) analisis sumber belajar. Analisis kurikulum dilakukan untuk mengetahui dan mengklarifikasi silabus yang dikembangan oleh kelompok bidang kajian mata kuliah Pengetahuan 
Lingkungan.Tujuan dari analisis kebutuhan penelitian ini adalah untuk: a) mengidentifikasi bahan ajar Pengetahuan Lingkungan yang sudah ada, b) mengidentifikasi kelemahan dan kelebihan bahan ajar yang sudah ada, c) mengidentifikasi permasalahan yang dihadapi mahasiswa dalam memahami materi pada sumber belajar dan d) menentukan materi yang akan dijabarkan pada website.

\section{Design /Desain}

Tahap perancangan (design) merupakan tahap untuk merancang media atau bahan ajar yang ingin dibuat. Tahap ini adalah membuat protype (produk awal) dan rancangan produk. Design memiliki 4 tahap. Tahap pertama adalah constructing criterion-referenced test, adalah tahap untuk membuat kerangka media pembelajaran yang ingin dibuat. Tahap yang kedua adalah tahap media selection, yaitu pemilihan media yang sesuai dengan materi pembelajaran. Tahap ketiga adalah format selection, yaitu tahap yang sangat erat kaitannya dengan media selection. Tahap ini merupakan tahap pemilihan penyajian pembelajaran yang disesuaikan dengan materi pembelajaran.

\section{Development/ Pengembangan}

Tahap pengembangan meliputi kegiatan membuat, mengembangkan memodifikasi dan uji coba bahan ajar berbasis website yang dikembangkan pada matakuliah Pengetahuan Lingkungan Tahapan pengembangan ini merupakan penjabaran dari tahapan desain. Uji coba produk bahan ajar Pengetahuan Lingkungan oleh para ahli yang melibatkan satu orang ahli materi Pengetahuan Lingkungan dan dua orang ahli media dan design pembelajaran. Selanjutnya dilakukan evaluasi formatif hasil validasi berupa revisi dari ahli materi Pengetahuan Lingkungan, dilanjutkan dengan evaluasi formatif hasil validasi berupa revisi dari ahli media dan desain pembelajaran. Sehingga dapat diketahui kekurangan dan kelebihannya, maka dilakukan perbaikan untuk mengurangi kelemahan tersebut.

Uji coba perorangan dan kelompok sedang dilakukan setelah mendapat validasi atau dinyatakan layak sebagai media pembelajaran Pengetahuan Lingkungan. Uji coba dilakukan kepada mahasiswa yang sudah menempuh mata kuliah Pengetahuan Lingkungan. Hasil uji coba digunakan dalam mengevaluasi bahan ajar Pengetahuan Lingkungan untuk melihat tingkat efisiensi dari website yang telah disusun. Evaluasi pada tahapan pengembangan bahan ajar Pengetahuan Lingkungan berbasis website dilakukan berdasarkan kritikan, saran, serta masukan ahli validasi materi serta ahli media dan desain pembelajaran. Kisi-kisi komponen yang akan divalidasi disajikan pada Tabel 1 dan Tabel 2.

Tabel 1 Kisi-kisi Instrumen Validasi Ahli Materi Pembelajaran

\begin{tabular}{lll}
\hline $\begin{array}{l}\text { Komponen divalidasi Ahli Pengetahuan } \\
\text { Lingkungan }\end{array}$ \\
\hline $\begin{array}{l}\text { Bahan } \\
\text { ajar }\end{array}$ & Ketepatan jalam \\
& merepresentasikan isi \\
& Kesesuaian judul bab dengan uraian \\
& utama \\
& Keoperasionalan tujuan pembelajaran. \\
& Kesesuaian tujuan pembelajaran dan \\
& isi materi \\
& Keakuratan isi uraian utama \\
& Kemampuan uraian utama untuk \\
& menarik perhatian \\
& Kemampuan tampilan gambar dalam \\
mempermudah & pengetahuan. \\
& Penggunaan Bahasa yang komuikatif \\
& ataumudah dimengerti. \\
& Ketetapan rujukan yang dipilih untuk \\
menunjang bahasan pada uraian \\
utama. \\
Kemenarikan bahan ajar
\end{tabular}


Tabel 2 Kisi-kisi Instrumen Validasi Ahli Media dan Desain Pembelajaran

\begin{tabular}{cl}
\hline \multicolumn{2}{c}{ Komponen divalidasi Ahli Media \& Desain } \\
Pembelajaran
\end{tabular}

Angket penilaian berisi kolomkolom yang menunjukkan skor dari setiap komponen yang divalidasi. Kriteria penilaian bahan ajar dapat dilihat pada Tabel 3.

Tabel 3. Kriteria Penilaian Bahan Ajar

\begin{tabular}{cc}
\hline Skor & Indikator \\
\hline 1 & Jika tidak baik/tidak sesuai \\
2 & Jika kurang baik/tidak sesuai \\
3 & Jika Baik/sesuai \\
4 & Jika sangat baik/sangat sesuai \\
\hline
\end{tabular}

\section{Implementation/ Implementasi}

Tahap implementasi dilakukan dengan melaksanankan kegiatan pembelajaran dengan menggunakan bahan ajar berbasis website yang telah disusun pada matakuliah Pengetahuan Lingkungan dengan mengukur tingkatan motivasi.

\section{Evaluation/Evaluasi}

Tahap terakhir adalah melakukan evaluasi (evaluation). Evaluasi adalah proses untuk melihat apakah bahan ajar yang dikembangkan berhasil, sesuai dengan harapan awal atau tidak. Sebenarnya tahap evaluasi terjadi pada setiap empat tahap di atas. Evaluasi yang terjadi pada setiap empat tahap di atas itu dinamakan evaluasi formatif karena tujuannya untuk kebutuhan revisi (Supriatna dan Mulyadi, 2009). Revisi produk dilakukan terhadap draft pengembangan produk yaitu berupa bahan ajar Pengetahuan Lingkungan. Revisi didasarkan pada hasil validasi ahli materi dan ahli kegrafikan dengan mempertimbangkan media \& desain pembelajaran,setelah didapatkan hasil validasi selanjutnya dilakukan perbaikan dan penyempurnaan draft bahan ajar sehingga dihasilkan produk akhir yang memenuhi kriteria.

\section{Teknik Analisis Data}

Terdapat dua teknik analisis data yang digunakan untuk mengolah data dari hasil tinjauan para ahli, yaitu menggunakan analisis diskriptif kualitatif dan diskripsi kuantitatif.

\section{Analisis deskriptif kualitatif}

Analisis deskriptif kualitatif digunakan untuk mengolah data dari hasil review para ahli. Teknik analisis data ini digunakan dengan mengelompokkan informasi-informasi dari data hasil kualitatif yang berupa tanggapan dan saran perbaikan dari validasi ahli materi dan validasi ahli media dan desain pembelajaran. Analisis data dijadikan acuan untuk memperbaiki atau merevisi produk.

\section{Analisis deskriptif kuantitatif}

Untuk menganalisis skor yang terkumpul dari lembar validasi, maka digunakan statistik. Data dari lembar validasi dianalisis untuk mendapatkan gambaran tentang bahan ajar yang dikembangkan. Setelah lembar validasi terkumpul, kemudian dihitung 


\begin{tabular}{|c|c|c|c|}
\hline $\begin{array}{lll}\text { persentase } & \text { dari } & \text { tiap-tiap butir } \\
\text { pertanyaan } & \text { nada } & \text { lembar validasi }\end{array}$ & $\begin{array}{l}\text { Tingkat } \\
\text { Pencapaian }\end{array}$ & Kualifikasi & Ketel \\
\hline $\begin{array}{l}\text { tersebut dengan persamaan yang } \\
\text { digunakan yaitu: }\end{array}$ & $\begin{array}{l}81-100 \\
61-80 \\
41-60\end{array}$ & $\begin{array}{l}\text { Sangat baik } \\
\text { Baik } \\
\text { Cukup baik }\end{array}$ & $\begin{array}{l}\text { Tidak perlu revisi } \\
\text { Tidak perlu revisi } \\
\text { Direvisi }\end{array}$ \\
\hline $\mathrm{P}=\frac{\Sigma(\text { keseluruhan jawaban angket })}{\mathrm{N} x \text { bobot tertinggi } x \text { jumlah responden }} \times 100 \%$ & $\begin{array}{l}21-40 \\
0-20\end{array}$ & $\begin{array}{l}\text { Kurang baik } \\
\text { Sangat kurang baik }\end{array}$ & $\begin{array}{l}\text { Direvisi } \\
\text { Direvisi }\end{array}$ \\
\hline Keterangan: & 3. Analisis & Motivasi & Belajar \\
\hline $\mathrm{P} \quad=$ Persentase penilaian & Mahasiswa & & \\
\hline $\begin{array}{l}\text { Pemberian makna dan pengambilan } \\
\text { keputusan tentang kualitas produk buku } \\
\text { terdapat Tabel } 4 \text { tentang kriteria tingkat } \\
\text { validitas yaitu. }\end{array}$ & \multicolumn{3}{|c|}{$\begin{array}{l}\text { Pengukuran motivasi mahasiswa } \\
\text { dengan menggunakan beberapa deskrtiptor } \\
\text { untuk uji coba kelompok sedang, seperti } \\
\text { pada tabel } 5\end{array}$} \\
\hline
\end{tabular}

Tabel 4. Pengambilan Keputusan Revisi Buku Ajar

Tabel 5. Kisi-kisi Instrumen Angket Motivasi

\begin{tabular}{|c|c|c|}
\hline Aspek & No & Pernyataan \\
\hline \multirow{3}{*}{$\begin{array}{l}\text { Attention } \\
\text { (Perhatian) }\end{array}$} & 1 & Saya lebih senang belajar pengetahuan lingkungan dengan website \\
\hline & 2 & Materi pembelajaran melalui website ini sangat menarik perhatian \\
\hline & 3 & Pada pembelajaran berbasis website ini ada hal-hal yang merangsang rasa ingin tahu saya \\
\hline \multirow{3}{*}{$\begin{array}{l}\text { Relevance } \\
\text { (Keterkaitan). }\end{array}$} & 4 & $\begin{array}{l}\text { Saya dapat menghubungkan isi pembelajaran di dalam website ini dengan hal-hal yang telah saya } \\
\text { lihat, saya lakukan, atau saya pikirkan di dalam kehidupan sehari-hari }\end{array}$ \\
\hline & 5 & $\begin{array}{l}\text { Pembelajaran berbasis website ini sangat relevan dengan kebutuhan saya sebab sebagian besar } \\
\text { isinya tidak saya ketahui }\end{array}$ \\
\hline & 6 & Materi pembelajaran melalui website ini lebih mudah dipahami daripada yang saya harapkan \\
\hline \multirow{3}{*}{$\begin{array}{c}\text { Confident } \\
\text { (Kepercayaan } \\
\text { diri) }\end{array}$} & 7 & $\begin{array}{l}\text { Pertama kali saya melihat pembelajaran berbasis website ini,saya percaya bahwa pembelajaran } \\
\text { ini mudah bagi saya }\end{array}$ \\
\hline & 8 & Bahasa yang digunakan di dalam website ini sangat mudah dipahami \\
\hline & 9 & Isi materi di dalam website ini akan bermanfaat bagi saya \\
\hline \multirow{3}{*}{$\begin{array}{l}\text { Satisfaction } \\
\text { (Kepuasan) }\end{array}$} & 10 & Memahami materi Pengetahuan Lingkungan dalam pembelajaran ini membuat saya merasa puas \\
\hline & 11 & $\begin{array}{l}\text { Saya telah mempelajari sesuatu yang sangat menarik dan tak terduga melalui pembelajaran } \\
\text { berbasis website }\end{array}$ \\
\hline & 12 & Saya merasa senang menyelesaikan dengan berhasil pembelajaran berbasis website ini \\
\hline
\end{tabular}

Motivasi mahasiswa diamati dengan menggunakan lembar observasi. Melalui skor yang diperoleh mahasiswa dapat ditentukan peningkatan motivasi belajar mahasiswa.Adapun penentuan persentase per deskriptor sebagai berikut.

$$
\begin{gathered}
\text { motivasi }=\frac{\sum \text { skor yang dicapai }}{\sum \text { skor maksimal }} \times 100 \% \\
\text { nilai skor klasikal }=
\end{gathered}
$$

Smahasiswa tuntas nilai motivasi belajar individu $\sum$ lseluruh siswa $x 100 \%$

\section{HASIL DAN PEMBAHASAN}

\section{Data Hasil Validasi Ahli Materi Pengetahuan Lingkungan}

Produk pengembangan yang diberikan kepada ahli isi materi Pengetahuan Lingkungan untuk mendapatkan penilaian dan tanggapan tentang bahan ajar berbasis website yang telah dikembangkan. Komentar dan saran ahli materi Pengetahuan Lingkungan dalam lembar validasi meliputi: a) memperbanyak 
gambar pada pengantar materi, memperjelas dan memerinci materi c) menambahkan tujuan pembelajaran pada rencana perkuliahan semester. Berdasarkan penilaian ahli materi, jumlah persentase keseluruhan untuk sebesar $80 \%$ dan dinyatakan telah memenuhi kriteria kualifikasi sangat menarik dan dapat digunakan tanpa revisi.

\section{Validasi Ahli Media dan Desain Pembelajaran}

Uji coba produk selain dilakukan oleh ahli isi mata kuliah Pengetahuan Lingkungan, juga dilakukan oleh ahli media dan desain pembelajaran. Berdasarkan rata-rata penilaian ahli ke-1 media dan desain desain website yaitu sebesar $93,75 \%$ dan ahli ke-2 media dan desain website $83,3 \%$. Dinyatakan telah memenuhi kriteria kualifikasi sangat menarik dan dapat digunakan tanpa revisi.

\section{Uji Coba Perorangan}

Produk pengembangan yang telah direvisi berdasarkan review ahli isi materi matakuliah serta ahli media dan desain pembelajaran, selanjutnya diuji coba pada tiga orang mahasiswa untuk mendapatkan komentar maupun saran terkait dengan keterbacaan. Data uji coba perorangan meliputi kesalahan ketik, kesalahan penggunaan tanda baca, kata yang seharusnya menggunakan huruf kapital atau huruf kecil, dan hal-hal lain yang perlu diperbaiki.

\section{Hasil Analisis Data}

Teknik analisis data yang digunakan dalam pengembangan produk bahan ajar adalah analisis persentase. Ada empat pilihan jawaban untuk setiap kriteria pernyataan pada setiap jenis angket yaitu: $1=$ untuk pilihan sangat kurang, $2=$ untuk pilihan kurang, $3=$ untuk pilihan baik, dan $4=$ untuk pilihan sangat baik. Hasil analisis dari ahli isi materi, ahli media dan desain pembelajaran, uji perorangan, disajikan pada Tabel 6 .

Tabel 6. Ringkasan Hasil Analisis data Validasi Produk

\begin{tabular}{clccc}
\hline No & \multicolumn{1}{c}{ Validator } & Juml & $\%$ & Ket. \\
\hline 1 & Ahli materi Materi & 32 & $80 \%$ & Baik \\
2 & $\begin{array}{l}\text { Ahli media dan desain } \\
\text { pembelajaran I }\end{array}$ & 45 & $93,75 \%$ & $\begin{array}{c}\text { Sangat } \\
\text { baik }\end{array}$ \\
3 & $\begin{array}{l}\text { Ahli media dan desain } \\
\text { pembelajaran II }\end{array}$ & 40 & $83,3 \%$ & $\begin{array}{c}\text { Sangat } \\
\text { baik }\end{array}$ \\
\hline
\end{tabular}

\section{Analisis data motivasi belajar mahasiswa}

Motivasi belajar mahasiswa dapat dilihat dari kegiatan mahasiswasaat uji coba klasikal sebanyak 35 mahasiswa. Aspek motivasi yang diukur didasarkan atas 4 macam tingkah laku yang menandai adanya peningkatan motivasi mahasiswa. Motivasi belajar mahasiswa dengan menggunakan bahan ajar berupa website dalam setiap aspek perhatian sebesar 91,4\% (sangat baik), pada aspek keterkaitan 84\% (baik), aspek kepercayaan diri 82,8\% (baik), dan aspek kepuasan $85,5 \%$ (sangat baik). Jadi berdasarkan data tersebut dapat diketahui bahwa bahan ajar berbasis website dapat meningkatkan motivasi belajar mahasiswa.

Bahan ajar berbasis website yang dihasilkan terdiri dari halaman depan, halaman profil, halaman materi, halaman, rencana pembelajaran semester (Gambar 2).

Pengembangan bahan ajar berupa website ini diharapkan dapat menjembatani indikator kompetensi yang harus dicapai oleh mahasiswa. Depdiknas menyebutkan bahwa bahan ajar adalah serangkaian alat yang digunakan untuk mencapai kompetensi yang harus dimiliki siswa/mahasiswa berupa pengetahuan, keterampilan atau materi pembelajaran (instructional materials). Secara terperinci, jenis-jenis materi 
pembelajaran terdiri dari pengetahuan yang meliputi fakta, konsep, prinsip, prosedur, keterampilan, dan sikap atau nilai (Depdiknas, 2006).

Bahan ajar memiliki peranan yang strategis dalam memfasilitasi kelancaran dalam proses pembelajaran (Sujarwo, 2008). Buku teks merupakan salah satu bahan ajar yang diperuntukkan bagi mahasiswa sebagai bekal pengetahuan dasar, dan digunakan sebagai sarana belajar dalam lingkup perkuliahan.

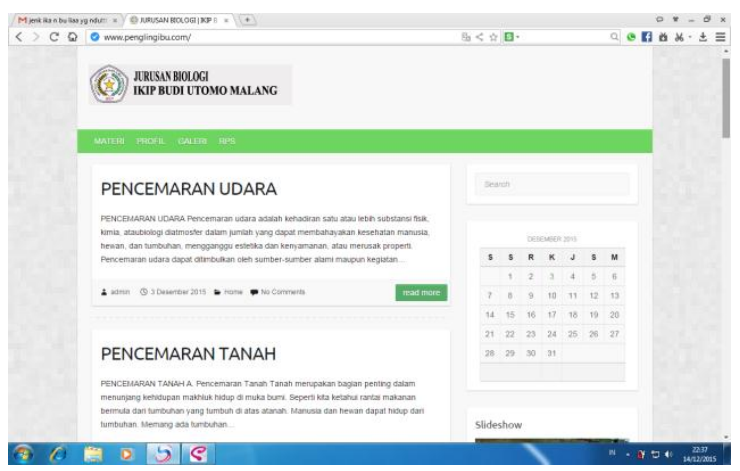

Gambar 2. Tampilan Halaman Depan

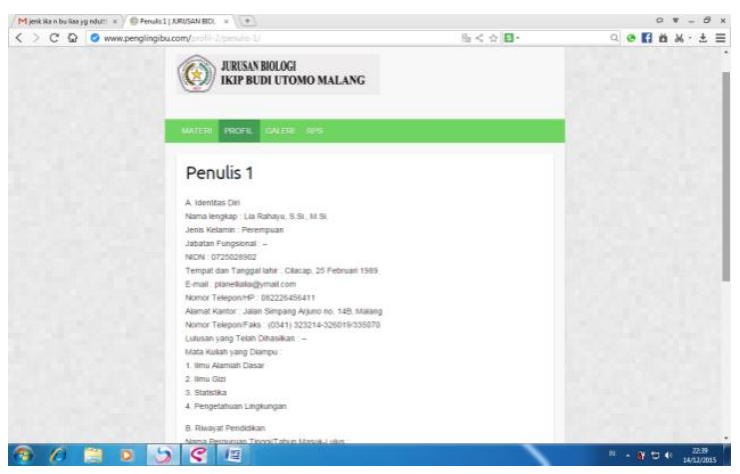

Gambar 3. Halaman profil penulis

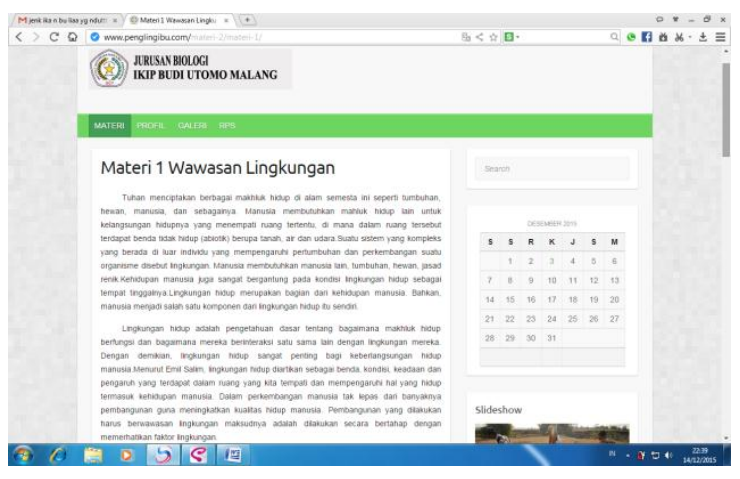

Gambar 4. Halaman materi

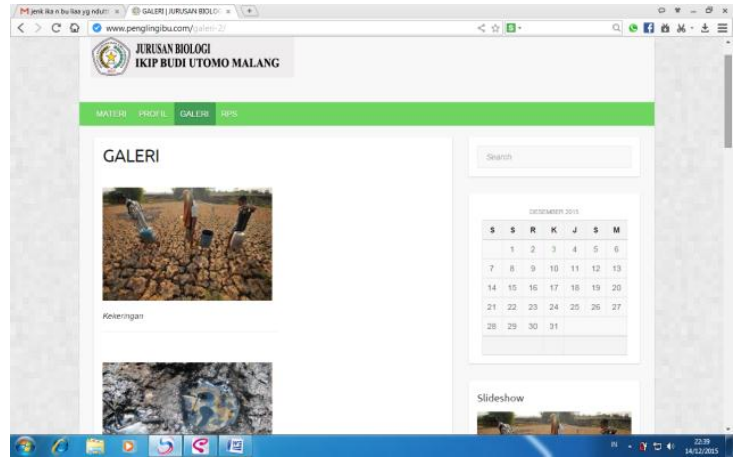

Gambar 5. Halaman Galeri

Dipandang dari proses pembelajaran, penggunaan bahan ajar mempunyai peran penting. Jika tujuan pembelajarannya adalah untuk menjadikan mahasiswa memiliki berbagai kompetensi, maka perancangan bahan ajar harus memasukkan sejumlah prinsip yang dapat meningkatkan kompetensi yang hendak dimiliki mahasiswa.

Kusdiyanti (2011) mengungkapkan bahwa, bahan ajar yang disusun dalam kaitan dengan kurikulum hendaknya memperhatikan tujuan tertentu yang hendak dicapai melalui pendidikan yang dilakukan dengan menggunakan buku pelajaran yang bersangkutan. Oleh karena itu, sebelum buku pelajaran itu dikembangkan, penyusun atau penulis harus terlebih dahulu memahami tujuan satuan pendidikan, tujuan pendididkan dan cakupan materi semester, kelas atau satuan pendidikan tertentu.

Hasil pengembangan bahan ajar berupa website pada matakuliah pengetahuan lingkungan, terdapat revisi yang dilakukan sesuai dengan prosedur penelitian pengembangan dengan mempertimbangkan saran dan masukan dari ahli isi materi, ahli media dan desain bahan ajar, serta dari uji perorangan dan kelompok sedang juga diperhatikan untuk penyempurnaan bahan ajar. Berdasarkan peraturan Menteri Pendidikan Nasional RI nomor 2 Tahun 2008 menjelaskan bahwa 
buku teks harus layak untuk dijadikan bahan ajar dan juga terdapat kriteria mutu (standart) bahan ajar pelajaran diantaranya, 1) kelayakan isi/materi, 2) kelayakan penyajian, 3) kelayakan bahasa, 4) kelayakan grafisan. Kriteria-kriteria tersebut telah tercantum dalam komponen lembar validasi yang dinilai oleh validator.

Hasil analisis data yang telah dilakukan terhadap pengembangan websitepada matakuliah pengetahuan lingkunganmenunjukkan hasil validasi bahan ajar layak untuk digunakan sebagai rujukan pada matakuliah pengetahuan lingkungan. Hasil kelayakan ini dilihat berdasarkan kebenaran materi yang disajikan pada websiteyaitu 80..Dengan adanya bahan ajar berbasis website ini diharapkan dapat membantu mahasiswa dalam memperoleh materi secara fleksibel dan efektif.

Validasi kelayakan website juga dilakukan pada ahli media dan desain pengembangan, tujuan dari validasi ini adalah untuk menilai fisik website yang membuat pembaca menyenangi buku yang dikemas dengan baik dan akhirnya juga meminati untuk membacanya sehingga dapat digunakan oleh mahasiswa. Hasil validasi ahli media dan desain mendapatkan nilai $93.75 \%$ dan $83,33 \%$, nilai tersebut menunjukkan kategori website layak dengan keputusan uji tidak perlu revisi. Nilai kelayakan ini menunjukkan bahwa website telah mencakup kriteria-kriteria yang harus dimiliki oleh bahan ajar.

\section{KESIMPULAN DAN SARAN}

\section{Kesimpulan}

1. Pengembangan website penunjang matakuliah Pengetahuan Lingkungan telah layak untuk digunakan karena sudah tervalidasi baik dan sangat baik oleh ahli materi dan ahli media dan desain pembelajaran.

2. Motivasi belajar mahasiswa dengan menggunakan bahan ajar berupa website dalam setiap aspek perhatian sebesar 91,4\% (sangat baik), pada aspek keterkaitan $84 \%$ (baik), aspek kepercayaan diri 82,8\% (baik), dan aspek kepuasan 85,5\% (sangat baik). Jadi berdasarkan data tersebut dapat diketahui bahwa bahan ajar berbasis website dapat meningkatkan motivasi belajar mahasiswa.

\section{Saran}

Bagi dosen yang ingin mempergunakan website pembelajaran sebaiknya (1) mempertimbangkan alokasi waktu dan biaya, (2) membuat perencanaan secara matang sebelum perkuliahan, terutama yang berkenaan dengan jadwal. Serta untuk pengembangan website sebagai bahan ajar agar diperbanyak halaman untuk wadah diskusi antra mahasiswa dengan dosen serta mahasiswa dengan mahasiswa.

\section{DAFTAR PUSTAKA}

Branch, R.M. (2009). Instructional Design: The ADDIE Approach. Speingger Science Business Media, LLC .

Departemen Pendidikan Nasional. (2008).

Kusdiyanti. Direktorat Jendral Manajemen Pendidikan Dasar Menengah.

Dimyati dan Mudjiono. (2006). Belajar dan Pembelajaran. Jakarta: Rineka Cipta.

Keputusan Menteri Pendidikan Nasional Republik Indonesia Nomor 232/U/2000 tentang Pedoman Penyususnan Kurikulum Pendidikan Tinggi Dan Penilaian Hasil Belajar Mahasiswa. (online http://luk.staff.ugm.ac.id/atur/Kepm en232/U-2000 Penyusunan 
Kurikulum Pdf), diakses 24 Maret 2015.

Kusdiyanti, Heny. (2011). Pelatihan Pengembangan Bahan Ajar Kearsipan Berbasis Potensi Lokal dalam rangka Program pemberdayaan Mahasiswa Binaan Labsosdik di SMK se-Malang. UM: LP3.

Nasution, Zulkarnain. Agustus (2012). Membangun Pencitraan Perdosenan Tinggi. Swara Pendidikan,4 (7):1415.

Rohman, M. dan Amri, S. (2013). Strategi dan Desain Pengembangan Sistem Pembelajaran. Jakarta: Prestasi Pustakakarya.

Sudjana, Nana. (2005). Penilaian Hasil Proses Belajar Mengajar. Bandung: PT.Remaja Rosdakarya.

Supriatna, Dadang, Mulyadi, Muhammad. (2009). Konsep Dasar Desain Pembelajaran. Pusat Pengembangan dan Pemberdayaan Pendidikan dan Tenaga Kependidikan Taman Kanak Kanak. Pdf.

Tsauri, A.S., Nugroho E. \& Wibisono, Y. (2009). Pengembangan Model Sistem E-learning Komunitas dengan Pendekatan Personal Learning Enviroments. Jurnal Pendidikan Teknologi dan Komunikasi, (Online), 2 (2): 2532,http://file.upi.edu/Direktori/JUR NAL/PENDIDIKAN_TIK/Jurnal_P end_TIK_Vol_2_No_2/PENGEMB ANGAN_MODEL_SISTEM_ELEA RNING_KOMUNITAS_DENGAN _PENDEKATAN_PERSONAL_LE ARNING_ENVIRONMENTS_(PL Es).pdf), diakses tanggal 20 Maret 2015.

Wijayanto, Serian. (2009). Pengelolaan Perdosenan Tinggi Secara Efisien,
Efektif, dan Ekonomis untuk meningkatkan Mutu Penyelenggaraan dan Mutu Lulusan. Jakarta: Salemba Empat. 